\title{
MODERNISASI PENDIDIKAN ISLAM DI INDONESIA: Kasus Adabiyah School
}

\author{
Mohammad Al Farabi \\ Universitas Islam Negeri Sumatera Utara Medan \\ Jl. Willem Iskandar Pasar V Medan Estate, Sumatera Utara, 20371 \\ e-mail:mohammad.alfarabi@uinsu.ac.id
}

\begin{abstract}
Modernization of Islamic Education in Indonesia: The Case of the Adabiyah School. The Dutch colonial mission to strengthen the power and expansion of Christian teachings in the archipelago took place with the establishment of educational institutions to prepare workers in the world of government bureaucracy and do not justify the inclusion of Islamic religious education materials in the Governorate Schools. Such conditions encourage the reaction of Muslim Modernists to rush to establish an independent educational institution that is considered capable of adapting as well as anticipating the development of the colonial mission. This reaction was marked for the first time by the establishment of Adabiyah School through the efforts and hard work of Abdullah Ahmad and supported by his comrades. This article aims to examine matters relating to the background of modernization in the Adabiyah institution and the efforts of modernization that have been made. Using historical research methods, this article reveals the historical fact that the Adabiyah School is the first Modern Islamic School in Indonesia that adheres to the classical system and competes with the Dutch colonial education system by developing a modern school to reduce the number of young Muslims attending education in the Gubernemen's School so that it is fostered personalities of citizens to practice Islam and not be influenced by the mission of Christianization brought by the Dutch invaders. Although the Adabiyah School did not last so long in historical development, the transmission of the modernization of education that it started had a strong influence on the rise of modern Islamic schools to this day.
\end{abstract}

Keywords: Adabiyah School, modernization, Islamic school 
Islamijah: Journal of Islamic Social Sciences, Volume 1, Number 3, September 2020: 248-271

\section{Pendahuluan}

Pendidikan Islam di Indonesia dalam sejarah awal pertumbuhannya berlangsung dengan pola yang amat sederhana dan bersifat kedaerahan. Proses perjalanan pendidikan pada masa pertumbuhan itu dimulai lewat aktivitas belajar dasardasar ilmu keislaman di lembaga-lembaga tradisional seperti surau di Sumatera Barat, meunasah di Aceh, langgar dan rajug di Pulau Jawa. Pada perkembangan selanjutnya, muncul pula lembaga pendidikan pesantren dengan ciri khas adanya pemondokan, masjid, kiai, kitab kuning dan santri. Dalam proses pendidikan ini, eksistensi kiai dipandang sebagai pemegang otoritas tunggal yang memiliki pengaruh besar dalam menginternalisasikan ilmu pengetahuan dan nilai-nilai keislaman yang terlaksana melalui pembelajaran kitab-kitab kuning dengan menggunakan metode sorogan dan wetonan. Dalam sistem pendidikan yang dijalankan, tidak terdapat aturan tentang disiplin waktu masuk dan tamatnya santri, tidak ada kurikulum yang terprogram secara akademik, tidak ada standar kelulusan santri, dan dalam operasionalisasinya tidak menggunakan fasilitas klasikal seperti kursi, meja dan papan tulis. Sistem pendidikan yang dijalankan cenderung eksklusif, dalam arti tidak membuka diri terhadap perkembangan zaman di sekitarnya dan menutup diri untuk tidak berinteraksi dengan dunia luar.

Pada awal abad ke-20, gagasan dan gerakan pembaharuan Islam di Indonesia mulai terbuka lebar dan terus bergulir secara berkesinambungan. Wilayah Minangkabau termasuk objek yang tidak terlepas dari pembaharuan itu, bahkan dapat dikatakan wilayah tersebut secara dominan mendapat sentuhan awal dari arus modernisasi pendidikan Islam. Banyak pemikir-pemikir baru lahir dari kalangan tokoh Islam Minangkabau, di antaranya adalah H. Abdullah Ahmad, seorang tokoh kelahiran Padang Panjang tahun 1878 yang mengawali pembaharuan di bidang pendidikan. Pembaharuan Minangkabau memberikan pengaruh besar terhadap kawasan lain di Indonesia misalnya Sumatera Utara. Al Washliyah (Ja'far: 2019; 2020) yang merupakan organisasi Islam asal Medan belajar mengenai pengelolaan pendidikan kepada pemuka Minangkabau dalam bidang pendidikan.

Syekh Abdullah Ahmad, tokoh pembaharu pendidikan Islam dari Sumatera Barat ini dikenal sebagai figur dan pemikir pendidikan yang memiliki gagasan tentang pentingnya membangun dunia baru Islam yang moderat dan dinamis 
serta menjanjikan pendidikan yang berkualitas untuk kemajuan masyarakat Islam. Karena itu, ia berupaya memperkenalkan sistem dan model pendidikan agama versi baru yang aktivitas pembelajarannya berlangsung di kelas dilengkapi bangku, meja, dan papan tulis, sebagaimana layaknya sekolah-sekolah gubernemen. Untuk mewujudkan kualitas lulusan yang memiliki daya saing dan kesiapan untuk masuk di dunia kerja, ia menerapkan kurikulum yang berstandar, visi lulusannya disesuaikan dengan perkembangan kebutuhan dunia pekerjaan, dan setiap siswa yang telah menyelesaikan studi diberi ijazah.

Secara lebih lanjut, artikel ini diarahkan untuk mengkaji modernisasi atau pembaharuan pendidikan Islam yang berobjek pada institusi pendidikan Adabiyah School, dengan terlebih dahulu memperkenalkan tolok ukur "modernisasi" Adabiyah, profil Abdullah Ahmad selaku pendirinya, sejarah pertumbuhan dan perkembangan Adabiyah, pemikiran modernisasi Abdullah Ahmad, dan disertai dengan analisis terhadap aspek modernisasi Adabiyah School.

Artikel dalam penelitian ini menggunakan metode penelitian sejarah (historical research) dengan menggunakan analisis-deskriptif untuk menghimpun fakta dan gagasan dari berbagai hasil penelitian dan pendapat dari para ahli sejarah disertai analisis yang terkait, sehingga dapat mengungkap aspek-aspek penting modernisasi pendidikan Islam yang pernah terjadi di institusi Adabiyah School. Sebelum penelitian tentang Adabiyah School ini dilakukan, sudah pernah terbit beberapa hasil penelitian sejarah yang mengungkap modernisasi pendidikan di lembaga-lembaga pendidikan Islam di Indonesia. Penelitian tersebut antara lain dilakukan Ahmadi Lubis berjudul Sekolah Islam terpadu dalam Sejarah Pendidikan Islam di Indonesia (2018) yang mengungkap bahwa konsep Sekolah Islam terpadu sudah muncul pada masa lalu melalui lembaga Adabiyah School, Diniyah School, Diniyah Putri, Normal Islam di Sumatra Barat, dan sebagainya. Selain itu, Mulyanto, et al., telah melakukan penelitian dengan judul Modernisasi Madrasah Awal Abad XIX (2019), namun hanya berfokus kepada studi analisis Madrasah Mambaul Ulum di Surakarta. Sepanjang pengetahuan peneliti, kajian modernisasi pendidikan Islam yang khusus meneliti lembaga Adabiyah School dengan menggunakan standarisasi (tolok ukur moderniasi) belum penah dilakukan oleh para peneliti sebelumnya. Atas dasar inilah peneliti memandang perlu kajian khusus tentang 
Islamijah: Journal of Islamic Social Sciences, Volume 1, Number 3, September 2020: 248-271

sisi keunikan modernisasi yang terjadi pada institusi Adabiyah School, sebab Sekolah Islam yang tidak bertahan begitu lama dalam perkembangan sejarah ini justru dapat menginspirasi dan memberikan pengaruh kuat terhadap bangkitnya sekolah-sekolah Islam modern pada periode sesudahnya hingga dewasa ini.

\section{Tolok Ukur Modernisasi Adabiyah School}

Kata “modernisasi” berasal dari akar katanya “modern”, yang berarti "terbaru atau sikap dan cara berpikir serta cara bertindak sesuai dengan tuntutan zaman" (KBBI, 2007). Istilah modernisasi sering pula disebut sebagai pembaharuan. Dengan demikian modernisasi pendidikan Islam dapat diartikan sebagai pembaharuan pendidikan Islam. Ada beberapa peristilahan yang mengandung pengertian hampir bersamaan dengan pembaharuan atau modernisasi, di antaranya inovasi (innovation), perubahan (change), reformasi (reform), rekonstruksi (reconstruction) dan restrukturisasi (restructuring).

Adapun konsep "modernisasi” menurut Milles, harus memiliki karakteristik bersengaja (deliberate), mengandung kebaruan (novel), lingkupnya spesifik (specific) dan mengarah pada pencapaian tujuan. Perlu dimaklumi bahwa menurut Rogers, bentuk modernisasi bisa berupa gagasan, praktik atau benda (misalnya produk teknologi) yang mengandung kebaruan bagi orang-orang yang akan menerima atau menggunakannya, dan karena itu tingkat keberterimaan (acceptability) modernisasi itu harus sangat diperhitungkan, terutama yang berkaitan kadar kebaruan itu sendiri. Karena itu, "keberterimaan oleh pihak pengguna" dapat ditambahkan sebagai karakteristik kelima dari modernisasi. Dengan demikian, setidak-tidaknya ada lima karakteristik modernisasi yang dapat digunakan untuk menilai sejauh mana suatu gagasan, praktik, atau benda dapat disebut dan dikategorikan "modernisasi” yakni kebersengajaan, kebaruan, kekhususan, kesesuaian dengan tujuan dan keberterimaan oleh pengguna.

Dilihat dari aspek individu-individu atau pihak yang menggunakannya, sehingga dapat diketahui sejauh mana tingkat penerimaan mereka terhadap suatu modernisasi, Rogers mengidentifikasi lima karakteristik inovasi sebagai 
berikut. Pertama, manfaat relatif (relative advantage); yakni sejauh manakah suatu inovasi dinilai lebih baik dibandingkan dengan apa yang telah ada sebelumnya. Manfaat relatif bisa dilihat dari kacamata ekonomi, prestise, kenyamanan, dan kepuasaan pengguna. Kedua, kompatibilitas (compatibility); yakni seberapa jauh inovasi itu konsisten dengan sistem nilai yang berlaku di lingkungan tempat inovasi itu diimplementasikan, pengalaman-pengalaman masa lalu, dan kebutuhan dari pengguna. Inovasi yang sesuai dengan hal-hal tersebut akan lebih cepat diadopsi daripada yang tidak sesuai atau bertentangan. Ketiga, kompleksitas (complexity); yakni sejauh manakah inovasi itu dipersepsi mudah atau sulit dipahami dan digunakan oleh (bakal) penggunanya. Makin sulit suatu inovasi dipahami dan digunakan, makin besar kemungkinannya untuk ditolak. Keempat, kedapatdicobaan (trialability); yakni sejauh manakah suatu inovasi dapat dicobakan dalam lingkup yang terbatas (terlebih dahulu) oleh pengguna, tidak mesti langsung dalam lingkup besar-besaran. Kelima, keteramatan hasilnya (observability); yakni seberapa jauh inovasi itu dapat dengan cepat atau mudah diamati hasilnya. Makin mudah pengguna melihat hasil inovasi, makin besar peluangnya untuk menerima inovasi itu.

Selanjutnya, yang dimaksud dengan "pendidikan Islam” adalah proses bimbingan, pengajaran, dan latihan terhadap suatu generasi yang pola dan sistem penyelenggaraannya dikembangkan dari ajaran dan nilai-nilai dasar yang terkandung dalam Alquran dan Hadis. Term "pendidikan Islam” juga dapat dipahami maknanya sebagai sistem pendidikan yang Islami, yang memiliki komponenkomponen yang secara keseluruhan mendukung terwujudnya sosok Muslim yang diidealkan (Muhaimin, 2006). Bertolak dari kedua konsep ini, istilah "pendidikan Islam" yang dimaksud dalam pembahasan tulisan ini adalah "pendidikan formal yang dilaksanakan dengan landasan ajaran dan nilai-nilai Alquran dan Hadis Nabi saw., yang aksentuasinya pada aspek institusi (lembaga) pendidikan dan sistem yang dijalankannya”. Dalam hal ini, institusi dan sistem pendidikan yang dimaksud adalah Adabiyah School.

Kemudian untuk mengukur "ada atau tidaknya" unsur-unsur modernisasi pendidikan Islam pada institusi Adabiyah School tersebut, instrumen pengukuran yang digunakan melalui kriteria-kriteria “modernisasi” yang dikemukakan oleh Milles dan Rogers, sebagaimana yang telah dipaparkan di atas. 
Islamijah: Journal of Islamic Social Sciences, Volume 1, Number 3, September 2020: 248-271

\section{Abdullah Ahmad dan Adabiyah School}

Abdullah Ahmad adalah pembaharu asal Kota Padang Panjang yang lahir pada tahun 1878. Ayahnya bernama H. Ahmad, seorang ulama Minangkabau dan saudagar kain Bugis. Abdullah Ahmad memulai pendidikan dengan mengkaji ilmu-ilmu agama Islam di bawah asuhan kedua orang tuanya dan sejumlah guru di daerahnya. Oleh orang tuanya, ia kemudian dimasukkan ke sekolah kelas 2 di Padang Panjang. Sekolah ini diberikan untuk pribumi di Padang Panjang.

Memasuki usia 17 tahun (1895), Abdullah Ahmad pergi ke Makkah untuk menunaikan ibadah haji. Kemudian, ia memanfaatkan kesempatan ini untuk meneruskan pelajaran agamanya kepada Syekh Ahmad Khatib yang merupakan ulama asal Minangkabau yang sudah bermukim di Makkah sebelumnya. Selama 4 tahun belajar di Makkah, Abdullah Ahmad mengamati perkembangan gerakan Wahabiyah yang berkembang saat itu. Gerakan Wahabiyah berupaya menghapus praktik bidah, khurafat dan tahayul, dan juga masalah taqlid. Kemudian, Abdullah Ahmad pulang ke Minangkabau pada tahun 1899. Setelah itu, ia mendedikasikan ilmunya di Surau Jembatan Besi Padang Panjang dengan menjadi seorang guru. Di sini, ia menerapkan cara mengajar tradisional, yaitu dengan sistem halaqah.

Abdullah Ahmad kemudian mereformasi sistem pengajaran tradisionalnya dengan sistem sekolah agama yang diberi nama Adabiyah School. Proses pembelajaran dengan sistem klasikal ini menggunakan sarana yang biasa terdapat pada sekolah yang dilaksanakan pemerintahan Belanda, seperti meja, bangku, dan papan tulis. Keadaan ini mendapat resistensi dari kalangan ulama tradisional, karena dianggap meniru cara-cara yang digunakan orang kafir. Karena resistensi tersebut sangat kuat, Abdullah Ahmad akhirnya memutuskan untuk pindah ke Padang pada tahun 1909. Ia kemudian menjadi guru di Masjid Raya Ganting. Ia menggantikan posisi pamannya Syekh Abdul Halim yang meninggal dunia.

Usaha Abdullah Ahmad untuk mengembangkan pendidikan tiada henti sampai akhir hayatnya. Ia dikenal sebagai tokoh yang memiliki komitmen keislaman yang tinggi, tetapi membuka diri untuk menerima perkembangan modern, dan demi kemajuan pendidikan Islam, ia siap melakukan tindakan kooperatif dengan pemerintah Hindia Belanda yang berkuasa saat itu, bila dipandang hal demikian lebih menguntungkan dari aspek kemaslahatan umat Islam. 
Modernisasi Pendidikan Islam ... (Al Farabi)

Kendati usia Adabiyah School yang didirikannya tidak terlalu panjang, tetapi dalam catatan sejarah di Indonesia, Abdullah Ahmad adalah tokoh terdepan yang berhasil memberi contoh bagi generasi berikutnya dalam hal pengembangan sekolah Islam modern di tanah air. Gerakan modernisasi yang ia lakukan akhirnya diikuti pula oleh institusi pendidikan yang muncul berikutnya, seperti Madras School yang didirikan oleh M. Thaib Umar (1910), Madrasah Muhammadiyah yang didirikan oleh Ahmad Dahlan (1912), Diniyah School yang didirikan oleh Zainuddin Labai (1915), Arabiyah School yang didirikan oleh Syekh Abbas (1918), dan sebagainya. Abdullah Ahmad meninggal dunia pada tahun 1934 dan dimakamkan di Padang.

\section{Adabiyah School sebagai Sekolah Islam Modern Pertama di Indonesia}

Adabiyah School sebagai sekolah Islam modern pertama di Indonesia sering disebut sebagai lembaga pendidikan yang menjadi perintis pembaharuan pendidikan Islam di Nusantara. Melalui tokoh pendirinya, H. Abdullah Ahmad, sekolah ini sempat berkembang pesat, seiring dengan tradisi masyarakat Minangkabau yang saat itu gemar menggeluti pembelajaran ilmu-ilmu keislaman. Sebagai pelopor pembaharuan di Minangkabau, Abdullah Ahmad sejak masa mudanya juga sering berkecimpung dengan berbagai aktivitas pembelajaran ilmu-ilmu keislaman di kampung halamannya. Sejak masa mudanya, ia aktif mengikuti pendidikan di surau-surau, kemudian melanjutkan menuntut ilmu-ilmu agama di Makkah sekitar 5 tahun, kemudian pulang kembali ke tanah air membantu ayahnya (yang juga seorang ulama) dalam menyelenggarakan kegiatan-kegiatan pengajian di surau Padang Panjang.

Aktivitas menyelenggarakan pengajian-pengajian agama semakin meningkat tatakala Abdullah Ahmad pindah ke Padang tahun 1906. Setelah aktif menjalani kegiatan-kegiatan tabligh dan pertemuan yang dilakukan untuk membahas kajian agama, satu tahun berikutnya ia mendirikan perkumpulan Adabiyah. Pada mulanya, perkumpulan ini terdiri dari dari delapan orang murid-muridnya yang aktif melakukan pengajian agama secara berkesinambungan. Pada perkembangan 
selanjutnya bertambah menjadi 300 orang, dan sebagian dari mereka yang ikut berkumpul menghadiri pengajian agama itu terdiri dari orang-orang dewasa.

Dengan aktifnya pengajian agama tersebut, Abdullah Ahmad termotivasi untuk merubah sistem pembelajaran tradisionalnya itu menuju sistem sekolah Islam modern yang diberi nama Adabiyah School. Nama lembaga ini secara simbolik mengilustrasikan kebangkitan ilmu pengetahuan sebagai pilar utama kebangkitan peradaban Islam, dan sebagian ahli sejarah memperkirakan nama Adabiyah diilhami oleh hadis Nabi Muhammad saw. yang diriwayatkan Ibn alSam'ani "Tuhanku telah mendidikku, maka Dia memberikan yang terbaik dalam pendidikanku" (Al-Syaukani, 1987).

Dalam catatan sejarah, Adabiyah School didirikan Abdullah Ahmad pada tahun 1907, tepatnya dalam kurun delapan tahun setelah ia kembali menuntut ilmu dari Makkah. Hasrat untuk mendirikan sekolah Islam modern itu sudah tertanam sejak lama, ketika ia dijejali oleh gagasan-gagasan brilian kaum modernis dari Timur Tengah seperti Muhammad 'Abduh. Namun dalam tataran praktisnya, ia baru mendirikan Sekolah Islam setelah melakukan kontak intensif dengan koleganya di Singapura, Tahir Jalaluddin. Bahkan pada tahun 1906, ia sengaja mengunjungi langsung temannya itu untuk tujuan utama mendirikan sekolah yang ia dambakan. Tahir Jalaluddin sendiri termasuk kaum pembaharu yang sudah merencanakan mendirikan sekolah modern di Singapura. Rencananya itu sudah dipublikasikan di majalah al-Imam terbitan Singapura yang juga beredar di Padang dan Abdullah Ahmad selalu membacanya. Di samping kontak dengan Tahir Jalaluddin, keinginan kuat Abdullah Ahmad untuk mendirikan Sekolah Adabiyah juga tumbuh karena melihat tertib dan baiknya sekolah gubernemen di Padang (Maksum, 1999).

Abdullah Ahmad tertarik untuk mendirikan pendidikan yang sistematis di bawah naungan Adabiyah, sebab tidak semua anak-anak dari Padang Panjang dapat masuk ke sekolah-sekolah pemerintah (Noer, 1980). Pada awalnya Sekolah Adabiyah didirikan di Padang Panjang yang merupakan kampung halamannya. Sistem pendidikan sekolah ini sangat berbeda dengan cara pendidikan di surau. Meskipun Abdullah Ahmad pemilik Surau Jembatan Besi, namun dia lebih tertarik untuk mengelola sekolah-sekolah modern daripada membina suraunya 
(Asrohah, 1999). Secara konsisten, ia menyelenggarakan sekolah itu dengan mengajarkan ilmu-ilmu agama dan ditambah dengan pelajaran membaca dan menulis Latin serta ilmu hitung. Jika dalam pendidikan di surau tidak dilakukan secara per kelas, maka dalam rencana pendidikan di Sekolah Adabiyah diatur berdasarkan kelas. Dalam rencananya yang ideal, Sekolah Adabiyah diharapkan menjadi semacam sekolah gubernemen Islam yang membawakan watak pembaharuan dengan misi pembebasan umat dari sikap taklid.

Menjelang dua tahun, Sekolah Adabiyah itu gagal berkembang, baik karena alasan situasi sekitarnya maupun karena alasan kondisi Abdullah Ahmad sendiri. Sejak masa awal pendiriannya, sekolah itu mendapat tantangan dari masyarakat Padang Panjang yang kebanyakan tidak menyukai pola pendidikan yang diterapkan Abdullah Ahmad. Kalau tidak karena kegigihannya, Sekolah Adabiyah ini sebenarnya tidak akan bisa berdiri lagi karena hampir tidak mendapatkan murid, sebab di wilayah itu masyarakat masih terpaku dengan sistem surau. Caranya yang terlalu drastis dalam melakukan pembaharuan, membuat sosok Abdullah Ahmad ini tidak memperoleh dukungan penuh dari ulama dan masyarakat. Di lokasi sekolah itu, Abdullah Ahmad juga berjualan kain untuk mendukung biaya operasional lembaga pendidikannya. Meskipun sudah berjualan, kegiatan bisnisnya itu kurang menguntungkan. Ditambah lagi fasilitas yang tersedia di wilayah tersebut juga tidak cukup untuk mendukung cita-citanya dalam hal penerbitan surat kabar.

Tidak patah semangat, Abdullah Ahmad memindahkan (Sekolah Adabiyah) itu ke Padang. Di kota ini ia mempelopori berdirinya "Syarikat Oesaha" (pada tahun 1914), karena ia berpandangan bahwa untuk mencapai kemajuan ekonomi dan pendidikan, perlu sebuah organisasi (Asrohah, 1999). Melalui organisasi itu, dalam waktu singkat ia sudah memiliki pelanggan-pelanggan usaha penjualan kainnya. Tidak seperti halnya di Padang Panjang, kehadiran Sekolah Adabiyah di Padang mendapatkan sambutan yang menggembirakan dari para pedagang, meskipun tetap mendapat tantangan dari kalangan ulama dan masyarakat awam. Perkembangan sekolah ini di Padang mencapai kemajuan yang cukup berarti, antara lain karena kurikulumnya lebih menekankan pada mata pelajaran umum yang hampir menyerupai HIS. Untuk meningkatkan mutu pendidikan 
di Sekolah itu, Abdullah Ahmad melibatkan empat guru berbahasa Belanda. Untuk bisa mengajar di tingkat HIS, beberapa guru dari kalangan pribumi pun disyaratkan memiliki ijazah.

Mata pelajaran agama di HIS hanya diberikan dua kali satu minggu. Selebihnya dialokasikan untuk mata pelajaran umum dan keterampilan membaca, menulis dan berhitung. Karena kualitas pendidikan dan kurikulum pengajarannya, sekolah ini mendapatkan pengakuan dari pemerintah Belanda pada tahun 1915. Kondisi seperti ini, memperlihatkan bahwa Sekolah Adabiyah merupakan sekolah Islam pertama setingkat HIS yang didirikan oleh kalangan Islam Minangkabau, dan bahkan mungkin juga pertama di Indonesia. Sekolah ini populer juga dengan sebutan HIS Adabiyah (Yunus, 1989). Namun demikian, berbeda dengan HIS yang terbatas bagi kalangan bangsawan dan pegawai, Sekolah Adabiyah terbuka untuk umum selama dapat berkontribusi dengan membayar uang pendidikan yang tidak begitu mahal. Karena itulah, kalangan pedagang sangat suka dengan sekolah ini sehingga mengirimkan anak-anak mereka untuk belajar di sekolah tersebut.

Jika diperhatikan dari aspek kurikulumnya, muatan pembelajaran Sekolah Adabiyah memang lebih mirip dengan sekolah Belanda. Agaknya Abdullah Ahmad sebagai pendirinya sangat terpengaruh dengan sistem sekolah yang dikembangkan Belanda itu, sehingga oleh masyarakat dipandang terlalu berlebihan dalam mengubah sistem pendidikan Islam. Meskipun aktivitas pendidikan sekolah berlangsung dengan sistem pembelajran formalnya, Abdullah Ahmad juga menyelenggarakan pengajian-pengajian mingguan. Hal ini menunjukkan bahwa aktivitas ia jalankan dalam pengembangan pendidikan Islam tidak hanya di sekolah, tetapi juga di masyarakat.

Dalam catatan sejarah, gagasan dan usaha pembaharuan pendidikan Islam di Minangkabau tidak pernah surut dan berhenti, meskipun Abdullah Ahmad telah meninggal dunia. Pengaruh yang dibangun Abdullah Ahmad dalam meletakkan dasar-dasar pendirian Sekolah Islam modern, pada kenyataaan diikuti oleh tokoh-tokoh lain sesudahnya. Merekajuga mendirikan dan mengembangkan sekolah, meskipun pola pendidikan yang mereka terapkan tidak terlalu mirip dengan sekolah ala Belanda. Bentuk sekolah yang terakhir ini agaknya lebih memperoleh sambutan dari masyarakat luas, sehingga jumlah sekolah bertambah sampai ke 
desa-desa di wilayah Minangkabau. Mungkin para pendiri sekolah-sekolah itu dapat banyak belajar dari akibat yang diterima Abdullah Ahmad, karena caranya yang sangat drastis dalam mengubah pendidikan Islam (Maksum, 1999).

\section{Pemikiran Abdullah Ahmad dalam bidang Pendidikan}

Sebagai salah seorang tokoh reformis Minangkabau yang banyak terpengaruh oleh Taher Jalaluddin, Abdullah Ahmad aktif dalam bidang pendidikan dan persuratkabaran (media komunikasi-pers). Di samping memberikan pelajaranpelajaran agama, pada tahun 1909 ia mendirikan sekolah dasar di Padang, yaitu Sekolah Adabiyah. Konon inspirasi sekolah Adabiyah itu berasal dari Sekolah Al-Iqbal al-Islamiyah yang didirikan oleh Taher Jalaluddin di Singapura (Noer, 1980). Sekolah ini menggabungkan kurikulum pendidikan umum dan agama secara simultan. Pada periode awalnya, sekolah Adabiyah ini dimasuki oleh mayoritas anak-anak kaum pedagang Sumatera Barat yang tidak mendapat tempat di sekolah pemerintah Kolonial Belanda.

Sekolah Adabiyah telah dikenal oleh publik luas sebagai institusi yang menganut sistem pendidikan modern. Hal demikian tentu saja dilatarbelakangi oleh pendirinya Abdullah Ahmad yang gemar mengintegrasikan nilai-nilai keislaman dengan perkembangan modern. Selain aktif di bidang pendidikan, Abdullah Ahmad juga giat sebagai penulis. Ia menerbitkan majalah Al-Munir yang terbit antara 1911-1915 di Padang. Al-Munir bertujuan menyebarkan agama Islam melalui pengetahuan para pembacanya dan sekaligus mempertahankan Islam dari serangan-serangan luar. Majalah ini memuat karangan-karangan tentang keagamaan yang mengemukakan pentingnya pengetahuan, manfaat surat kabar dan pentingnya arti perkumpulan sebuah organisasi. Al-Munir juga menaruh perhatian kepada peristiwa-peristiwa penting di dunia (Noer, 1980).

Perkembangan majalah Al-Munir selama lima tahun mendapat sambutan dari masyarakat luas. Dalam operasionalnya sehari-hari, majalah Al-Munir dibantu oleh tiga orang staf redaksi tetap, yaitu H. Abdul Karim Amrullah (ayah buya Hamka), Muhammad Taib Umar, dan Muhammad Jamil Jambek. Majalah ini terbit dua minggu sekali dengan menggunakan bahasa Melayu-Arab. Jangkauan 
majalah ini meliputi daerah Sumatera, Jawa, Kalimantan, Sulawesi, dan Malaysia (Ambary et al., 2003).

Dalam majalah Al-Munir inilah, H. Abdullah Ahmad, H. Abdul Karim Amrullah, dan kawan-kawan mengemukakan fatwa mereka yang dianggap baru dan bertentangan dengan fatwa kaum tradisional di Padang ketika itu, seperti berfoto hukumnya boleh, dan memakai dasi dan topi tidak haram. Oleh sebab itu majalah Al-Munir dianggap sebagai sarana penyebarluasan paham yang dibawa oleh H. Abdullah Ahmad dan kawan-kawannya. Majalah ini hanya bertahan sampai tahun 1915 karena kesulitan biaya.

Di samping itu, pada tahun 1913, Abdullah Ahmad juga aktif menerbitkan majalah Al-Akhbar dan menulis aktif di majalah Al-Islam yang diterbitkan pertama kali oleh Syarikat Islam Surabaya pada tahun 1916. Ia selanjutnya membuat aliansi permanen dengan Abdul Karim Amarullah (bergelar Inyiek Rasul) dan Muhammad Jamil Jambek (bergelar Inyiek Jambek). Aliansi yang didirikan itu bertujuan untuk menggerakkan reformisme Islam di Padang. Setelah menghadiri Konferensi Internasional Islam di Mesir pada tahun 1925, Abdullah Ahmad dan Amarullah dianugerahkan gelar Doktor Honoris Causa di Al-Azhar.

Adapun konsep atau ide-ide pendidikan yang dikemukakan Abdullah Ahmad paling kurang meliputi tiga aspek yang fundamental, yaitu aspek kelembagaan, aspek metode, dan aspek kurikulum. Ketiga aspek ini dapat dikemukakan sebagai berikut:

\section{Konsep Pemerataan Pendidikan}

Pada masa pemerintahan kolonial Belanda, Abdullah Ahmad dan warga masyarakat Padang dan sekitarnya mendapat perlakuan yang amat diskriminatif. Pada masa itu, pemerintah Belanda membagi sekolah menjadi tiga strata, yaitu 'Strata Atas' untuk kalangan Belanda, 'Strata Menengah' untuk masyarakat bumiputra yang memiliki kemampuan ekonomi dan 'Strata Rendah' bagi anakanak bumiputra lain yang berekonomi rendah, yaitu Sekolah Desa selama tiga tahun. Melihat realitas ini, ia berkeinginan untuk mendirikan sekolah Islam yang sistem pengajarannya hampir sama dengan HIS milik Belanda, sebagai 
bentuk ikhtiar pemerataan pendidikan, sehingga dunia pendidikan tidak hanya yang dapat dinikmati oleh sekelompok kaum bangsawan saja, tetapi juga dapat dinikmati semua kalangan, baik kelompok miskin maupun menengah.

\section{Aspek Kelembagaan}

Salah satu ide pembaharuan pendidikan yang dibawa oleh Abdullah Ahmad adalah bidang kelembagaan atau institusi pendidikan. Perencanaan Abdullah Ahmad tatkala hendak mendirikan Sekolah Adabiyah, ia terlebih dahulu menghubungi beberapa orang yang memiliki pendidikan guru dan beberapa orang dari kalangan ulama. Untuk mendukung kegiatan lembaga ini, Abdullah merekrut para pegawai yang berjiwa kebangsaan, yaitu mereka yang memiliki legalitas terhadap pemerintah Belanda dengan tujuan untuk menghilangkan kecurigaan pemerintah Belanda.

Pada tahun 1915 corak pendidikan Adabiyah diubah menjadi Holands Maleische School (HMS) atau Hollands Inlandsch School (HIS), yaitu tingkat pendidikan setaraf dengan Sekolah Dasar (SD) seperti yang ada sekarang. Berdirinya HIS Adabiyah ini sebagai reaksi terhadap politik pemerintah Hindia Belanda yang mendirikan HIS (Holand Inlandse School) yang sekuler. HIS Adabiyah menampung umat Islam yang tidak memperoleh kesempatan untuk belajar di sekolah Belanda (Nata, 2001). Pada institusi ini, selain diajarkan pengetahuan umum, juga diajarkan pelajaran agama dan Al-Qur'an sebagai mata pelajaran wajib (Noer, 1980).

Dengan adanya perubahan tersebut, Adabiyah School mendapatkan subsidi dari pemerintah kolonial, yaitu berupa kucuran dana dan tenaga guru. Pada perkembangan selanjutnya, jenjang pendidikan sekolah ini bertambah dengan berdirinya Taman Kanak-kanak (TK), SD, SMP, dan SMA, bahkan ada pula Sekolah Tinggi Administrasi Islam (STAI) serta laboratorium komputer.

Kemodernan lembaga pendidikan Adabiyah ditandai oleh adanya sikap keterbukaan terhadap para siswa yang berasal dari berbagai golongan untuk belajar di sekolah ini, asalkan dengan syarat beragama Islam. Sementara untuk memenuhi standarisasi tenaga pengajar, Abdullah Ahmad memilih guru yang berbobot, setara dengan guru-guru yang mengajar di sekolah Belanda. 
Islamijah: Journal of Islamic Social Sciences, Volume 1, Number 3, September 2020: 248-271

\section{Aspek Metode Pengajaran}

Metode diskusi (debate) adalah metode yang diterapkan oleh Abdullah Ahmad di Sekolah Adabiyah. Metode ini memberikan kesempatan seluas-luasnya kepada murid untuk bertanya dan berdialog secara terbuka tentang berbagai hal. Hal demikian dilakukan sebagai upaya mengubah cara lama yang menempatkan para siswa secara pasif dalam belajar dan kurang diberikan kebebasan, sementara waktu dipergunakan lebih banyak oleh guru.

Metode lainnya yang perlu diterapkan menurut Abdullah adalah metode bermain dan rekreasi. Menurutnya, anak-anak perlu diberi waktu untuk bermain dan bersenang-senang serta beristirahat dalam proses belajar-mengajar yang sedang berlangsung. Karena jika tidak ada waktu beristirahat, dapat merusak perilaku anak yang semula baik, karena bosan dengan kegiatan yang banyak menguras daya pikirnya. Akibat lainnya, hatinya akan mati, pemahamannya terhadap bahan pelajaran yang diberikan akan tumpul serta cahaya akalnya akan padam.

\section{Aspek Kurikulum}

Sebagaimana dicatat dalam sejarah bahwa perubahan Sekolah Adabiyah menjadi HIS Adabiyah terjadi pada tahun 1915. Dalam hal ini Mahmud Yunus menegaskan, Adabiyah adalah HIS pertama yang memasukkan mata pelajaran agama dalam kegiatan pembelajarannya, di samping mengajarkan mata pelajaran umum.

Abdullah Ahmad memandang bahwa dunia pendidikan harus mengimplementasikan konsep integrasi. Sebab, pendidikan Islam harus mampu melahirkan lulusan menguasai ilmu-ilmu pengetahuan umum dan teknologi modern, di samping penguasaan dasar-dasar ilmu keislaman yang kuat. Dengan demikian sangat diperlukan berdirinya suatu sekolah yang dapat menerapkan kolaborasi antara keduanya. Berdirinya Adabiyah School adalah jawaban atas tujuan dimaksud.

Sebagaimana yang telah dijelaskan sebelumnya, bahwa Sekolah Adabiyah bercorak agama dengan sistem modern. Kurikulum yang diterapkan oleh Abdullah 
Ahmad adalah konsep kurikulum pendidikan integrated (integrated curriculum of education), yaitu terpadunya pengetahuan umum dengan pengetahuan agama serta bahasa dan keterampilan dalam program pendidikan.

\section{Anggaran Biaya Pendidikan}

Dengan adanya perubahan menjadi HIS, Adabiyah berhasil mendapatkan subsidi dari pemerintah kolonial Belanda, yaitu berupa biaya operasional sekolah dan sejumlah tenaga guru. Hal tersebut memperlihatkan bahwa Abdullah Ahmad berhasil menghilangkan kecurigaan pemerintah kolonial terhadap Adabiyah yang sebenarnya menjadi pesaing misi pendidikan sekuler yang dilakukan oleh pemerintah Hindia Belanda.

\section{Tinjauan terhadap Aspek Modernisasi Adabiyah School}

Misi pendidikan yang dikembangkan oleh Belanda untuk menyebarkan ajaran Kristen di Indonesia dan tidak membenarkan masuknya materi pendidikan agama Islam di sekolah-sekolah negeri (gubernemen), ternyata memberikan reaksi bagi kaum Modernis Muslim di Indonesia untuk melakukan gerakan baru yang mampu menjawab tantangan kolonialisme dan ekspansi Kristen (Suminto, 1996). Gerakan yang dilakukan kaum Modernis Muslim itu berlangsung sejak awal abad ke-20 dengan suatu gagasan bahwa mereka memandang perlu melakukan pembaharuan terhadap sistem pendidikan Islam (Azra, 1999). Pembaharuan terhadap sistem tersebut dilakukan melalui upaya mendirikan sekolah-sekolah umum model Belanda, tetapi diberi muatan pengajaran agama Islam. Tanpa dapat dipungkiri secara faktual, ide ini pertama kali dicetuskan oleh Abdullah Ahmad dengan mendirikan Sekolah Adabiyah di Padang Panjang tahun 1907 (Steenbrink, 1986).

Berbeda dengan pendidikan di surau, pada Sekolah Adabiyah, sistem klasikal diterapkan dan dilaksanakan secara konsekuen. Di samping pelajaran agama, pelajaran membaca dan menulis huruf Latin serta ilmu hitung dalam sekolah ini juga diberikan. Namun rencana sekolah ini gagal dan belum sampai usia dua tahun, sekolah ini sudah ditutup dan dipindahkan ke Padang (Steenbrink, 
1986). Setelah pindah ke Padang, Sekolah Adabiyah ini berjalan jauh lebih maju dibanding ketika masih berada di Padang Panjang. Dalam proses pembelajarannya, pendidikan umum lebih ditekankan dari pada pendidikan agama. Hal ini disebabkan pendidikan umum sangat laku di Padang. Untuk memperbaiki mutu pendidikan umum, Abdullah memasukkan empat orang guru berbangsa Belanda, di samping dua orang Indonesia yang juga mempunyai ijazah untuk mengajar di tingkat HIS. Pada tahun 1916 sekolah Adabiyah ini diakui oleh Pemerintah Belanda sebagai HIS pertama yang didirikan oleh organisasi Islam. Dengan adanya pengakuan atas keabsahan sekolah ini, setahun berikutnya mendapat subsidi penuh dari gubernemen (Rahardjo, 1985).

Perbedaan antara Sekolah Adabiyah dengan HIS yang lain di Padang, terletak pada pemberian pelajaran agama 2 jam per minggu, yang diberikan oleh Abdullah Ahmad sendiri. Sekolah HIS lain pada umumnya hanya terbuka bagi anak-anak pegawai dan keluarga tertentu saja, sedangkan sekolah Adabiyah terbuka untuk semua anak-anak dari berbagai kalangan, baik anak pejabat sampai anak yang berasal dari rakyat jelata.

Menurut Karel A. Steenbrink, Sekolah Adabiyah ini sebenarnya merupakan bentuk adaptasi diri dari sistem surau kepada suatu penyesuaian total terhadap sistem Barat (Steenbrink, 1986). Akibat seringnya melakukan kontak hubungan dan beradaptasi dengan pemerintah kolonial, sekolah ini terbawa arus sehingga semakin lama perhatiannya terhadap pendidikan agama semakin kecil. Karena itu mayoritas kalangan ulama tradisional Minangkabau tidak dapat menerima perubahan sistem pendidikan yang demikian. Pada akhirnya sekolah Adabiyah tidak mampu bertahan lama dan eksistensinya hilang dari pentas dunia pendidikan.

Kendatipun Abdullah Ahmad belum maksimal untuk mengadakan pembaharuan di bidang agama akibat penyesuaian diri kepada sistem pendidikan Barat, tetapi ia telah dikenal selaku tokoh modernis yang mampu menyaingi sistem pendidikan Belanda dalam model yang hampir sama, sehingga dapat mengurangi jumlah masyarakat Islam di Sumatera Barat yang hendak memasuki sekolah gubernemen.

Model yang sama dengan kegiatan pendidikan Abdullah Ahmad muncul pada masa belakangan. Sekolah yang memiliki kesamaan model itu adalah sekolah-sekolah umum/kejuruan yang didirikan oleh organisasi Muhammadiyah 
seperti Volkschool, Standartschool, HIS, Schakelschool dan MULO, yang pada umumnya mengadopsi kurikulum sekolah-sekolah Hindia Belanda, ditambah pengajaran agama Islam untuk menampilkan identitas "keislamannya" dan sekaligus membedakannya dengan sekolah-sekolah gubernemen Belanda.

Meskipun Muhammadiyah waktu itu dituding melakukan pendangkalan iman oleh kalangan tradisional yang lebih mempertahankan model pendidikan pesantren, ternyata tidak menggoyahkan mereka dalam memperluas sekolahsekolahnya. Menurut Hadikusuma, sekolah-sekolah itu didirikan oleh Muhammadiyah justru untuk mengantisipasi besarnya kecenderungan umat Islam terutama dari kalangan menengah, memasukkan anaknya ke sekolah-sekolah Belanda, yang lebih menjanjikan masa depan mobilitas sosial. Dengan adanya sekolahsekolah seperti yang didirikan Muhammadiyah itu, para orang tua Muslim tidak perlu lagi mengirim anak-anaknya ke sekolah-sekolah Belanda, karena telah disediakan Muhammadiyah. Selain kurikulum dan mutunya sama, ada lagi pelajaran agama yang tentunya tidak diperoleh di sekolah Belanda. Dengan cara itu, peserta didik yang memilih sekolah umum tetap terpelihara agamanya (Hadikusuma, t.t.).

Pada masa pemerintahan kolonial Belanda ini, sekolah-sekolah umum yang didirikan Muhammadiyah seperti Volkschool, Vervolgschool, Standartschool, HIS, Schakelschool, MULO, AMS dan HIK, masing-masing mengajarkan agama Islam sebanyak 4 jam seminggu. Sementara pelajaran lainnya yang bersifat umum mengadopsi kurikulum sekolah gubernemen secara penuh tanpa perubahan (Kemenag RI, 1986). Dilihat dari kegiatan pembelajaran ini, nampaknya Muhammadiyah mengikuti pola yang sama dengan kegiatan yang dilakukan Abdullah Ahmad di Padang. Persamaan tersebut lebih terlihat pada upaya pendirian sekolah umum swasta yang mengikuti model pendidikan gubernemen dengan ditambah beberapa jam pelajaran agama per minggu.

Dengan demikian dapat dikatakan bahwa, sekolah Adabiyah yang didirikan Abdullah Ahmad dan sekolah-sekolah umum Muhammadiyah merupakan lembaga pendidikan umum yang memiliki kepedulian dan perhatian terhadap perlunya penyelenggaran pendidikan agama Islam di tengah merebaknya pendidikan ala Hindia Belanda pada masa sebelum kemerdekaan. Dengan tidak sepenuhnya 
mengikuti Barat, pada masa itu mereka dapat dikatakan mampu menyaingi pendidikan kolonial Belanda untuk kepentingan masyarakat Islam, walaupun secara implisit makna perjuangan mereka tidak disadari sepenuhnya oleh masyarakat, terutama bagi golongan tradisional yang konservatif.

Keberadaan pendidikan agama Islam di sekolah-sekolah pada masa sebelum kemerdekaan ini, nampaknya kurang mengalami perkembangan sebagaimana mestinya. Dikatakan demikian, karena pada masa penjajahan Belanda pintu masuk pendidikan modern bagi umat Islam terbuka secara sempit. Kondisi seperti ini terjadi setidak-tidaknya dilatarbelakangi oleh dua faktor utama. Pertama, sikap dan kebijakan pemerintah kolonial yang amat diskriminatif terhadap kaum Muslim. Kedua, politik nonkooperatif para ulama terhadap Belanda yang menfatwakan bahwa ikut serta dalam budaya Belanda, termasuk pendidikan modernnya adalah suatu bentuk penyelewengan agama (Saidi, 1984).

Di kala pemerintah kolonial Belanda bersikap diskriminatif terhadap pergerakan pendidikan Islam dan kaum Muslim, Abdullah Ahmad nampaknya mampu menjalankan sistem pendidikan Adabiyah School yang terlepas dari ancaman dan perlakuan diskriminatif itu. Hanya saja, dalam menjalankan misi modernisasi pendidikan Islam, Abdullah Ahmad menghadapi satu tantangan yang cukup serius selama berada di Padang Panjang, yakni rongrongan ulama konservatif yang bernota bene belum memahami atau tidak dapat menerima gerakan modernisasi.

Kendatipun institusi pendidikan Adabiyah School tidak bertahan lama dalam perjalanan masa, namun Abdullah Ahmad dapat dikatakan "modernisator" yang berhasil dalam meletakkan dasar dan contoh pendirian serta pengembangan sekolah Islam modern pertama di Indonesia. Upaya modernisasi yang telah ia lakukan akhirnya diikuti pula oleh insitusi pendidikan menyusul berikutnya, antara lain Madras School yang didirikan oleh M. Thaib Umar (1910), Madrasah Muhammadiyah yang didirikan oleh Ahmad Dahlan (1912), Diniyah School yang didirikan oleh Zainuddin Labai (1915) dan Arabiyah School yang didirikan oleh Syekh Abbas (1918).

Bila kembali merujuk pada kriteria-kriteria “modernisasi” yang digagas oleh Milles dan Rogers, nampaknya pemikiran dan gerakan yang diaktualisasikan 
Abdullah Ahmad pada Adabiyah School telah memenuhi persyaratan untuk layak dikategorikan upaya "modernisasi”. Kelayakan dari persyaratan dimaksud dapat ditelaah pada berbagai aspek. Pertama, kebersengajaan. Abdullah Ahmad pada hakikatnya bertujuan ingin menyaingi sistem pendidikan kolonial Belanda dan mengembangkan sekolah modern, sehingga didirikanlah Adabiyah School yang pola pendidikannya mirip dengan sekolah Gubernemen. Selain itu, ia juga ingin mengurangi jumlah generasi muda Islam mengikuti pendidikan di Sekolah Gubernemen yang dilaksanakan oleh Pemerintah Hindia Belanda. Dari aspek tujuan didirikan Adabiyah School ini memperlihatkan bahwa gagasan dan tindakan Abdullah Ahmad mengandung unsur "kebersengajaan".

Kedua, kebaruan. Untuk kasus di Indonesia saat itu, Adabiyah School dapat dikatakan sebagai Sekolah Islam Modern pertama yang menganut "sistem pendidikan klasikal”. Adabiyah memperlihatkan ciri baru yang berbeda dengan pendidikan di surau-surau yang tidak menggunakan kelas, tidak memakai bangku, meja, papan tulis, dan hanya duduk bersila saja (Yunus, 1989). Selain itu, dalam sejarah modernisasi pendidikan Islam di Indonesia, Adabiyah tercatat institusi pendidikan "pertama” yang berperan sebagai madrasah (sekolah agama) tidak hanya di Minangkabau, tetapi juga "pertama” di seluruh Indonesia (Daulay, 2007).

Ketiga, kekhususan. Adabiyah School memiliki misi khusus, yaitu untuk membangun pendidikan Islam yang bermutu dengan mempersiapkan mentalitas dan pengamalan akidah masyarakat yang kokoh agar tidak terkontaminasi dengan berbagai bentuk ajaran dan misi Kristenisasi yang digulirkan Pemerintah Kolonial Belanda. Dalam konteks ini, Adabiyah School dapat dipahami punya misi laten (tersembunyi) untuk menghempang gerakan misionaris Kristen yang dilancarkan oleh pemerintah Hindia Belanda.

Keempat, relevansi dengan tujuan sistem. Adabiyah School bertujuan mengkombinasikan pola pendidikan umum model Belanda yang diwarnai oleh sistem pendidikan Islami. Karena itu, kurikulum yang diterapkan Adabiyah adalah integrated curriculum. Guru-guru Muslim yang mengajar di lembaga ini diseleksi ketat dan dipilih bobotnya yang sama dengan guru-guru di Sekolah Belanda. Pada bidang studi umum yang dianggap perlu peningkatan kualitas, 
dilengkapi dengan 4 orang guru profesional dari Belanda. Kesemua ini dilakukan untuk peningkatan efektifitas dan kualitas dari tujuan dan sistem pendidikan secara keseluruhan.

Kelima, keberterimaan oleh pengguna. Meskipun mendapat tantangan dari kelompok kaum tradisional Muslim di Padang Panjang, namun ketika pusat operasi pendidikan Adabiyah beralih ke Padang, ternyata mendapat sambutan yang signifikan dari masyarakat. Hal ini menunjukkan bahwa misi pendidikan yang dijalankan Adabiyah School sesungguhnya adalah baik, hanya saja tingkat intelektualitas masyarakat Padang Panjang yang berada di pedesaan belum mampu menjangkau orientasi dan nilai-nilai pendidikan yang digagas Abdullah Ahmad. Sebaliknya, dikala kemampuan intelektualitas masyarakat telah meningkat dan berada pada iklim perkotaan, gagasan dan gerakan modernisasi seperti yang dilakukan Abdullah Ahmad lebih dapat diterima.

Di sisi lain, ada beberapa hal yang menarik diungkap. Pertama, modernisasi pendidikan yang diterapkan di Adabiyah School dapat dikatakan relatif lebih baik bila dibandingkan dengan lembaga pendidikan sebelumnya, terutama pada aspek berikut. (1) Akidah. Bila dibanding dengan sekolah-sekolah umum/ gubernemen yang dimasuki oleh umat Islam sebelumnya, Adabiyah School memiliki bidang studi keislaman yang memperkuat akidah. (2) Ekonomi. Berbeda dengan sekolah-sekolah gubernemen yang hanya diperuntukkan bagi pihak yang mampu (kalangan anak-anak pejabat dan pegawai pemerintah Belanda), Adabiyah menampung warga masyarakat yang berekonomi lemah untuk bisa sekolah. Untuk menutupi kekurangan pembiayaan di sekolah ini, Abdullah Ahmad menggalang dana dari para pedagang (Syarikat Oesaha) demi kesinambungan program pendidikan yang dijalankan, sampai Adabiyah mendapat subsidi dari Pemerintah Belanda pada tahun 1915. (3) Prestise. Adabiyah diakui sebagai lembaga pendidikan yang legal oleh pemerintah kolonial Belanda, bila dibanding surau dan pesantren yang tidak mendapatkan pengakuan seperti itu. Hal ini meninggikan citra dan popularitas Adabiyah di tengah-tengah masyarakat. (4) Kenyamanan. Dikarenakan Adabiyah diakui pemerintah kolonial Belanda yang sedang berkuasa, warga masyarakat merasa nyaman dan terhindar dari intimidasi. 
Hal ini dirasakan penting oleh masyarakat, karena pada waktu itu perlakuan diskriminatif pemerintah kolonial Belanda terhadap gerakan pendidikan Islam dan kaum Muslim terjadi di mana-mana. (5) Kepuasan bagi pengguna. Adanya sikap keterbukaan Adabiyah kepada seluruh warga masyarakat yang berasal dari berbagai golongan untuk dapat belajar maksimal dengan syarat beragama Islam.

Kedua, sistem pendidikan yang dianut oleh Adabiyah School dapat dikatakan konsisten dengan sistem nilai yang berlaku di Padang, yaitu tetap mempertahankan nilai-nilai pendidikan Islam, di samping memerlukan penguasaan ilmu-ilmu umum. Kemudian, modernisasi yang terjadi pada Adabiyah School direspons oleh warga masyarakat dengan sikap mendukung (pro) dan menolak (kontra). Meskipun demikian, sikap pihak yang mendukung jauh lebih banyak bila dibandingkan dengan sikap pihak yang menolak. Hal ini ditandai dengan munculnya sekolahsekolah yang didirikan oleh organisasi Muhammadiyah, seperti Volkschool, Standartschool, HIS, Schakelschool, MULO; yang kesemuanya mencontoh model pendidikan Adabiyah. Terjadinya tarik menarik antara pihak yang mendukung dan menolak, membuktikan bahwa modernisasi di tubuh Adabiyah memiliki kompleksitas masalah. Gerakan modernisasi dikatakan unggul dan menjadi pemenang apabila berhasil atau lulus dari cengkraman kompleksitas masalah.

Ketiga, dalam kawasan masyarakat Padang yang pemahaman keislamannya telah moderat, kehadiran Adabiyah School disambut baik. Adapun sikap sebagian masyarakat Padang Panjang yang menolak kehadiran Adabiyah dilatarbelakangi karena mereka saat itu belum mengerti dan menyadari betapa pentingnya "modernisasi pendidikan Islam" di lingkungan mereka hidup.

Keempat, modernisasi yang terjadi pada Adabiyah School dapat dikategorikan "cepat" untuk dapat diamati hasilnya. Sebelum sampai pada masa kemerdekaan Indonesia saja, telah ditemukan banyak berdiri lembaga-lembaga pendidikan Islam yang mencontoh gerakan dan model pendidikan Adabiyah School sebagaimana yang telah dijelaskan terdahulu. Terlebih-lebih pada masa pasca kemerdekaan, buah perjuangan dari gebrakan awal Adabiyah School telah nampak dalam bentuk wujud nyata di tengah-tengah masyarakat Indonesia. 
Islamijah: Journal of Islamic Social Sciences, Volume 1, Number 3, September 2020: 248-271

\section{Penutup}

Dalam sejarah modernisasi pendidikan Islam di Indonesia, Adabiyah School tercatat sebagai institusi pendidikan "pertama” yang berperan sebagai madrasah (sekolah agama) tidak hanya di Minangkabau, tetapi juga "pertama" di seluruh Indonesia. Institusi pendidikan ini didirikan pada tahun 1907, oleh Abdullah Ahmad, seorang ulama moderat kelahiran Minangkabau. Ide untuk mendirikan sekolah ini terobsesi tatkala ia pulang dari Sekolah al-Iqbal al-Islamiyah di Singapura. Belum sampai dua tahun dari masa berdirinya Adabiyah School, institusi pendidikan ini menghadapi reaksi dan kecaman dari kelompok ulama konservatif di Padang Panjang. Melihat suasana yang tidak stabil itu, Abdullah Ahmad memindahkan pusat pendidikan yang diasuhnya ke kota Padang. Di lokasi baru ini, Adabiyah mendapat sambutan dan dukungan yang signifikan dari masyarakat Muslim yang lebih terbuka untuk menerima pembaharuan.

Kendati pun institusi pendidikan Adabiyah School tidak bertahan lama dalam perjalanan masa, namun ia dapat dikatakan sebagai "modernisator" yang berhasil dalam meletakkan pondasi dan contoh pendirian serta pengembangan sekolah Islam modern pertama di Indonesia. Upaya modernisasi yang telah ia lakukan akhirnya diikuti pula oleh insitusi-institusi pendidikan Islam yang muncul berikutnya, baik pada masa sebelum kemerdekaan maupun sesudahnya. Untuk kasus di Indonesia saat itu, Adabiyah School merupakan Sekolah Islam modern pertama yang menganut sistem pendidikan klasikal. Adabiyah memperlihatkan ciri baru yang berbeda dengan lembaga-lembaga pendidikan Islam tradisional lainnya yang tidak menggunakan kelas, bangku, meja, papan tulis, kurikulum modern dan ijazah. Adabiyah School bertujuan mengkombinasikan pola pendidikan umum model Belanda yang diwarnai oleh sistem pendidikan Islami. Karena itu, kurikulum yang diterapkan Adabiyah adalah integrated curriculum. Pada bidang studi umum yang dianggap perlu peningkatan kualitas, dihadirkan 4 orang guru profesional dari Belanda. Kesemua ini dilakukan untuk peningkatan efektivitas dan kualitas dari tujuan dan sistem pendidikan yang dijalankan. Sistem pendidikan yang dianut oleh Adabiyah School dapat dikatakan konsiten dengan sistem nilai yang berlaku di Padang, yaitu tetap mempertahankan nilainilai pendidikan Islam, di samping memerlukan penguasaan ilmu-ilmu umum. 
Modernisasi Pendidikan Islam ... (Al Farabi)

\section{Pustaka Acuan}

Ambary, Hasan Muarif (et al.). (2003). Suplemen ensiklopedi Islam, Jilid I. Ichtiar Baru Van Hoeve.

Asrohah, Hanun. (1999). Sejarah pendidikan Islam. Logos Wacana Ilmu.

Azra, Azyumardi. (1999). Pendidikan Islam: Tradisi dan modernisasi menuju millenium baru. Logos Wacana Ilmu.

Daulay, Haidar Putra. (2007). Sejarah pertumbuhan dan pembaruan pendidikan Islam di Indonesia. Prenada Media Grup.

Hadikusuma, Djarnawi. (t.t.). Matahari-matahari Muhammadiyah. Persatuan.

Hasbullah. (2006). Otonomi pendidikan: Kebijakan otonomi daerah dan implikasinya terhadap penyelenggaraan pendidikan. RajaGrafindo Persada.

Ja'far, J. (2019). Al Jam'iyatul Washliyah dan pelestarian akidah Ahl Sunnah wa al-Jama'ah di Indonesia. ISLAMICA: Jurnal Studi Keislaman, 14(1), $54-$ 81. https://doi.org/10.15642/islamica.2019.14.1.54-81.

Ja'far, J. (2020). Merantau demi republik: Kehidupan dan perjuangan Ismail Banda (1909-1951). Islamijah: Journal of Islamic Social Sciences, 1(2), 136161, http://dx.doi.org/10.30821/islamijah.v1i2.7181.

Ja'far, J. (2020). Ulama Mandailing awal abad ke-20: Gerakan religius dan politik Abdurrahman Sjihab (1910-1955). Islamijah: Journal of Islamic Social Sciences, 1(1), 1-25. http://dx.doi.org/10.30821/islamijah.v1i1.7155.

Kementerian Agama RI. (1986). Sejarah pendidikan Islam di Indonesia. Direktorat Jenderal Pembinaan Kelembagaan Agama Islam Kemenag RI.

Langgulung, Hasan. (2002). Peralihan paradigma dalam pendidikan Islam dan sains sosial. Gaya Media Pratama.

Maksum. (1999). Madrasah: Sejarah dan perkembangannya. Logos Wacana Ilmu.

Muhaimin. (2006). Nuansa baru pendidikan Islam: Mengurai benang kusut dunia pendidikan. RajaGrafindo Perasada.

Nata, Abuddin. (2005). Tokoh-tokoh pendidikan Islam di Indonesia. RajaGrafindo Persada.

Noer, Deliar. (1980). Gerakan modern Islam di Indonesia 1900-1942. LP3ES. 
Rahardjo, M. Dawam (ed.). (1985). Pergulatan dunia pesantren: Membangun dari bawah. P3M.

Ridjaluddin. (2001). Surau dan modernisasi pendidikan di masa Hindia Belanda. Dalam Abuddin Nata (ed.). Sejarah pertumbuhan dan perkembangan lembagalembaga pendidikan Islam di Indonesia. Grasindo.

Saidi, A. Ridwan. (1984). Pemuda Islam dalam dinamika politik bangsa 1925-1984. Rajawali Pers.

Shaleh, Abdul Rachman. (2006). Madrasah dan pendidikan anak bangsa: Visi, misi dan aksi. RajaGrafindo Persada.

Steenbrink, Karel. (1986). Pesantren, madrasah dan sekolah: Pendidikan Islam dalam kurun modern. LP3ES.

Suminto, Aqib. (1996). Politik Islam Hindia Belanda. LP3ES.

Syaukani, Muhammad ibn 'Ali ibn Muhammad. (1987). Al-Fawâ'id al-majmu'ah fi al-Ahâdits al-Maudhu'ah. Al-Maktabah al-Islamiy. Juz I.

Tim Penyusun Kamus Pusat Bahasa. (2007). Kamus besar bahasa Indonesia. Balai Pustaka.

Yunus, Mahmud. (1979). Sejarah pendidikan Islam di Indonesia. Hidayakarta Agung. 